\title{
Analisis Best Practice Inovasi Pelayanan Publik (Studi pada Inovasi Pelayanan “Kumis MbahTejo" di Kecamatan Tegalrejo Kota Yogyakarta)
}

\author{
Dwian Hartomi Akta Padma Eldo ${ }^{1}$, Dyah Mutiarin ${ }^{2}$
}

\begin{abstract}
ABSTRAK
Sampai saat sekarang ini masalah pelayanan publik menjadi perhatian bersama, dibutuhkan sebuah formula dalam bentuk inovasi agar pelayanan publik menjadi lebih baik lagi. Inovasi Pelayanan publik saat ini sudah menjadi tuntutan yang harus dijalankan oleh penyedia layanan, baik itu ditataran pemerintah Pusat ataupun Pemerintah Daerah. Setiap instansi Pemerintah dituntut untuk meningkatkan pelayanan publik kepada masyarakat dalam bentuk inovasi yang ada. Budaya inovasi harus melekat kepada pemerintah yang menyelenggarakan pelayanan harus bersifat dinamis dan tetap selalu berkembang karena saat sekarang ini dengan tingkat literatur yang tinggi masyarakat telah mengerti dan paham mengenai hak dan kewajiban mereka dalam pelayanan publik. Demi meningkatkan kualitas pelayanan maka Pemerintah Kecamatan Tegalrejo Kota Yogyakarta melakukan sebuah upaya inovasi pelayanan yang diberinama Kamis-Jum'at tambah tiga jam atau dikenal dengan istilah "Kumis Mbah Tejo". Penelitian ini bertujuan untuk melihat bagaimana pengimplementasian dari konsep Best practice didalam inovasi pelayanan dengan mencoba menganalisis dengan unsur-unsur dari Impact, partnership, sustainability, leadership dan transferability. Teknik pengumpulan data penulis mencoba melakukan dengan cara wawancara kepada pihak yang terkait. Untuk kesimpulan yang didapatkan dalam penelitian ini adalah inovasi pelayanan yang ada mendapatkan respon yang baik oleh masyarakat karena dampak dari inovasi ini bisa dirasakan langsung serta yang menarik adalah untuk mendapatkan kepuasan masyarakat dalam inovasi pelayanan "Kumis Mbah Tejo" ini tanpa perlu semua unsur yang menjadi landasan analisis terpenuhi dengan baik.
\end{abstract}

Kata Kunci: Inovasi, Pelayanan Publik, Pemeritah Kecamatan

ABSTRACT

Until now the problem of public services is a common concern, it takes a formula in the form of innovation so that public services are better. Today's public service innovation has become a demand that must be carried out by service providers, whether it is arranged by the Central Government or the Regional Government. Every Government agency is required to improve public services to the public in the form of existing innovations. The culture of innovation must be inherent in the government that organizes services that must be dynamic and always evolves because nowadays with a high level of literature the community understands and understands their rights and obligations in public services. In

${ }^{1}$ Dwian_hartomi@yahoo.com

22Mutiarin@yahoo.com 
order to improve the quality of service, the Tegalrejo Sub district Government of the City of Yogyakarta conducted an innovative service effort called Thursday-Friday added three hours or known as "Kumis Mbah Tejo". This study aims to see how the implementation of the Best practice concept in service innovation by trying to analyze with the elements of Impact, partnership, sustainability, leadership and transferability. Data collection techniques the author tries to do by interviewing the parties concerned. The conclusions obtained in this study are that service innovation is getting a good response from the community because the impact of this innovation can be felt directly and what's interesting is to get community satisfaction in this "Mustache Mbah Tejo" service innovation without the need for all the elements that become the foundation analysis is well fulfilled.

Key word : Innovation, Public Service, Sub district Governmental

\section{A. PENDAHULUAN}

Pasca dikeluarkannya Peraturan Menteri Negara Pendayagunaan Aparatur Negara dan Reformasi Birokrasi (PAN-RB) No. 15 Tahun 2008 tentang Pedoman Umum Reformasi Birokrasi menunjukkan keseriusan pemerintah dalam langkah awal terhadap penyelenggaraan pemerintah yang bersih. Semua lembaga negara baik dari tingkat pusat hingga daerah harus berbenah dan meningkatkan kualitas pelayanan yang diberikan kepada masayarakat demi tercapainya keinginan dan cita-cita dari reformasi birokrasi itu sendiri. Pemerintah semakin serius dalam pembenahan tata kelola pemerintahan saat ini dengan dikeluarkannya Peraturan Presiden (PP) Nomor 81 tahun 2010 tentang Grand Desain Reformasi Birokrasi 2010-2025 yang menjadi landasan bagi Kementrian/Lembaga/Pemerintah Daerah dalam melakukan reformasi birokrasi dalam rangka mewujudkan tata kelola pemerin-tahan yang baik.

Capaian dalam reformasi birokrasi adalah penyelenggaraan pemerintahan yang terbebas dari KKN, peningkatan kapasistas dan akuntabilitas serta penguatan orientasi ke arah peningkatan pelayanan publik yang dilakukan. Tujuan tersebut menjadikan reformasi birokrasi sebagai langkah pada tataran hulu, yakni langkah preventif yang prakteknya di negaranegara berkembang dan industri baru jauh lebih efektif dan berdampak panjang dibandingkan dengan aksi pemberantasan korupsi secara kuratif (Klitgaard, 1998).
Komitmen terkait Reformasi Birok-rasi tidak hanya pada tataran pemerintah pusat, namun sampai kepada Pemerintahan terendah sekalipun harus mulai menata sistem tata kelola pemerintahanya yang mampu mengedepankan kepentingan dan kepuasan masyarakat terhadap pelayanan termasuk Pemerintahan Kecamatan Seka-lipun. Meskipun Pemerintah Kecamatan bukan garda terakhir dalam penyelenggaraan pelayanan publik, namun peran pemerintah kecamatan sangat penting sebagai kepanjangan tangan dari pemerintah Kabupaten.

Peningkatan pelayanan publik (public service) harus mendapatkan perhatian utama dari pemerintah, karena pelayanan publik merupakan hak-hak sosial dasar dari masyarakat social rihgts ataupun fundamental rights (Holle, 2011). Pemerintah jangan sampai mengenyampingkan hak-hak yang dimiliki oleh rakyat dalam mendapatkan pelayanan yang terbaik, karena tugas dan fungsi negara adalah melindungi rakyat dan memenuhi segala kebutuhannya demi tercapai kesejahteraan sosial. Penolakan atau penyimpangan pemerintah dalam penyelenggaraan pelayanan publik adalah bertentangan dalam UUD 1945

Pada tahun 2015 Ombudsman RI Mencatat ada sebanyak 6.859 masalah yang terjadi dalam pelayanan publik dari seluruh wilayah Indonesia (Laporan Tahunan Ombudsman RI, Tahun 2015), itupun baru yang dilaporkan, belum masalah pelayanan yang belum dilaporkan. Laporan tahunan 2015 Ombudsman pada bagian penanganan 
pengaduan masyarakat dapat dilihat pada gambar 1 dibawah ini :

\section{Gambar 1}

Laporan Pengaduan

Masyarakat Terhadap

Pelayanan Publik

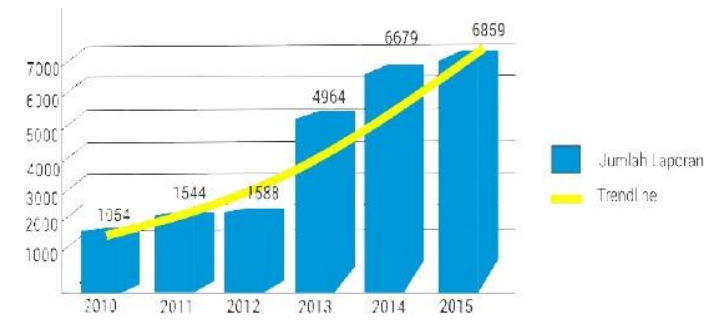

Sumber : Buku Laporan Tahunan 2015

Ombudsman RI. hal 18

Pada gambar hasil laporan Ombudsman pada tahun 2015 dapat dilihat bahwa dari tahun ke tahun ternyata pelayanan publik di Indonesia tidak ada perubahan untuk memberikan pelayanan yang baik kepada masyarakat. Mulai dari tahun 2013 sampai tahun 2015 terlihat bahwa laporan masyarakat kepada Ombudsman selalu meningkat, peningkatan tersebut jika dilihat ada beberapa faktor yang mempengaruhi yaitu : Pertama, semakin tingginya kesadaran masyarakat terhadap hak yang dimilikinya terhadap pelayanan yang diberikan pemerintah. Kedua, karena pemerintah sebagai penyelenggara pelayanan tidak benar-benar menjalankan amanat dalam UU No. 25 tahun 2009 tentang Standard Pelayanan Minimal. Beberapa faktor tersebut yang menjadikan selalu meningkatnya laporan terhadap kinerja pemerintah dalam bidang pelayanan publik.

Salah satu proses yang terpenting dalam upaya mewujudkan kesejahteraan masyarakat dalam pelayanan publik itu ialah dengan melakukan sebuah terobosan inovasi. Pada umumnya inovasi sering kali diterjemahkan sebagai penemuan hal baru, namun sebenarnya aspek "kebaruan" dalam inovasi sangat ditekankan untuk inovasi pada sektor swasta. Saat ini nilai sektor bisnis memang saatnya diadopsi oleh sektor Pemerintah "Corporate Values", belakangan bukan hanya mewabah dalam institusi korporasi, melainkan juga dalam dunia pemerintah. Walaupun inovasi saat ini masih ada yang pro dan kontra akan tetapi apabila inovasi tidak dilakukan maka tidak akan pernah ada pembaharuan atau perubahan (Kasali, 2012).

Inovasi pada sektor publik lebih ditekankan pada aspek "perbaikan" yang dihasilkan dari kegiatan inovasi tersebut, yaitu pemerintah mampu memberikan pelayanan publik secara lebih efektif, efesien dan berkualitas, murah dan terjangkau sesuai kebutuhan masyarakat. Inovasi di sektor publik merupakan salah satu jalan atau bahkan "breakthrough" untuk mengatasi kemacetan dan kebutuhan organisasi di sektor publik.

Selain menjalankan Pelayanan yang maksimal baik Pemerintah pusat maupun Pemerintah daerah juga dituntut untuk melakukan inovasi dalam sektor publik dengan area yang telah dijelaskan dalam Peraturan Presiden (PP) Nomor 81 tahun 2010 tentang Grand Desain Reformasi Birokrasi 2010-2025. Saat ini Inovasi dalam penyelenggaraan pelayanan publik tidak hanya dilakukan ditingkat pusat saja, namun ditingkat kecamatan juga diperlukan sebuah Inovasi pelayanan agar mampu memenuhi kebutuhan masyarakat pada bidang pelayanan publik. Kecamatan Tegalrejo merupakan salah satu Kecamatan yang ada di Kota Yogyakarta. Kecamatan Tegalrejo menjadi sorotan tersendiri oleh masyarakat karena inovasi pelayanan yang dilakuan oleh pemerintah Kecamatan Tegalrejo.

Pada umumnya pelayanan publik yang dilakukan oleh instansi pemerintah dilaksanakan pada hari kerja yaitu senin sampai jum'at yang setiap harinya dibatasi hanya 8 jam saja. Pelayanan publik pada hakekatnya memiliki tujuan untuk memuaskan atau sesuai dengan keinginan masyarakat atau pelanggan pada umumnya (Juliantara, 2005). Untuk mencapai hal ini diperlukan kualitas pelayanan 
yang sesuai dengan kebutuhan dan keinginan masyarakat. Tambahan jam pelayanan yang diberikan oleh Pemerintah Kecamatan Tegalrejo merupakan sebuah inovasi yang dilakukan untuk menjawab dari kebutuhan masyarakat di wilayah Tegalrejo.

Inovasi pelayanan dengan menambah jam pelayanan yang ada setiap Kamis-Jumat selama 3 jam per hari atau lebih dikenal dengan “Kumis Mbah Tejo". Inovasi pelayanan Kumis Mbah Tejo ini mulai diberlakukan November 2015, dan pada saat itu program ini masih diberi nama Jum'at Panjang, yang mana pada awalnya pelayanan diberikan hanya pada hari Jum'at saja yaitu sampai pada jam 20.30 malam. Seiring berjalanya waktu, kebijakan itu beganti hari menjadi seperti saat ini yaitu pada hari kamis dan Jum'at, sampai jam 18.00 WIB.

Pelayanan di kantor Kecamatan tidak jauh berbeda dengan di kantor lainnya. Pada pelayanan "Kumis Mbah Tejo" pelayanan yang diberikan tidak berbeda dengan pada jam kerja biasanya di kantor Kecamatan, agar bisa memenuhi segala kebutuhan masyarakat dalam bidang perijinan. Berikut pelayanan yang diberikan oleh kantor Kecamatan :

\section{Tabel 1}

\section{Standard Pelayanan Publik di Kecamatan Tegal Rejo}

\begin{tabular}{|l|l|c|c|}
\hline NO & \multicolumn{1}{|c|}{ JENIS PELAYANAN } & $\begin{array}{c}\text { JAM } \\
\text { KERJA }\end{array}$ & $\begin{array}{c}\text { KUMIS } \\
\text { MBAH TEJO }\end{array}$ \\
\hline 1. & $\begin{array}{l}\text { Izin Mendirikan } \\
\text { Bangunan }\end{array}$ & $\sqrt{ }$ & $\sqrt{ }$ \\
\hline 2. & Izin Gangguan & $\sqrt{ }$ & $\sqrt{ }$ \\
\hline 3. & $\begin{array}{l}\text { Izin lokasi Pedagang } \\
\text { Kaki lima (PKL) } \\
\text { Pelayanan Izin } \\
\text { Penyelenggaraan } \\
\text { reklame yang melekat } \\
\text { pada bangunan/ } \\
\text { gedung }\end{array}$ & $\sqrt{ }$ \\
\hline 4. & $\begin{array}{l}\text { Izin penyelenggaraan } \\
\text { Pondokan }\end{array}$ & $\sqrt{ }$ & $\sqrt{ }$ \\
\hline 5. & $\begin{array}{l}\text { Izin penggunaan tanah } \\
\text { makam }\end{array}$ & $\sqrt{ }$ & $\sqrt{ }$ \\
\hline
\end{tabular}

\begin{tabular}{|l|l|c|c|}
\hline 6. & $\begin{array}{l}\text { Izin perpanjangan } \\
\text { penggunaan tanah } \\
\text { pemakaman }\end{array}$ & $\sqrt{ }$ & $\sqrt{ }$ \\
\hline 7. & $\begin{array}{l}\text { Izin perpanjangan } \\
\text { penggunaan tanah } \\
\text { pemakaman }\end{array}$ & $\sqrt{ }$ & $\sqrt{ }$ \\
\hline 8. & $\begin{array}{l}\text { Izin perpanjangan } \\
\text { pemesanan tempat } \\
\text { pemakaman }\end{array}$ & $\sqrt{ }$ & $\sqrt{ }$ \\
\hline 9. & $\begin{array}{l}\text { Izin Pemesanan tempat } \\
\text { pemakaman }\end{array}$ & $\sqrt{ }$ & $\sqrt{ }$ \\
\hline
\end{tabular}

Sumber : Buku Standard Pelayanan Publik Kecamatan di Kota Yogyakarta

Keberadaan inovasi pelayanan "Kumis Mbah Tejo" di Kecamatan Tegalrejo saat ini merupakan salah satu bukti tanggungjawab pemerintah Kecamatan dalam peningkatan mutu dan kualitas pelayanan yang diberikan kepada masyarakat. Selain itu inovasi pelayanan "Kumis Mbah Tejo" dijadikan laboratorium penelitian oleh Lembaga Administrasi Negara (LAN) serta selalu dimonitoring dan evaluasi sampai saat sekarang ini.

Berdasarkan latar belakang yang telah diuraikan diatas, maka dari itu peneliti tertarik untuk melihat bagaimana Inovasi Pelayanan Publik "Kumis Mbah Tejo" disebut sebagai best practice dengan menganalisis dengan konsep best practice yang sudah pernah dikenalkan oleh UN Habitat, dan harapanya agar bisa menambahkan referensi kepada instansi Pemerintah lainnya untuk bisa memunculkan inovasi yang lainnya. Tujan dari penelitian ini adalah agar pemerintah daerah lain mampu mengadopsi inovasi pelayanan yang sudah ada dan mampu diterapkan di-daerahnya.

Maka dari itu peneliti mencoba menarik rumusan masalah dengan bagaimana analisis best practice dari Inovasi Pelayanan "Kumis Mbah Tejo" yang diterapkandi Kecamatan Tegalrejo Kota Yogyakarta?

\section{A. METODE PENELITIAN}

Jenis Penelitian yang digunakan dalam penelitian ini adalah jenis penelitian deskriptif kualitatif, yakni untuk menjelaskan bagaimana inovasi pelayanan "Kumis Mbah Tejo" di kecamatan Tegalrejo Kota Yogyakarta. Pene- 
litian kualitatif adalah penelitian yang bermaksud untuk memahami fenomena tentang apa yang dialami oleh subjek penelitian secara holistik dan dengan cara deskripsi dalam bentuk kata-kata dan bahasa, pada suatu konteks khusus yang alamiah dengan memanfaatkan berbagai metode alamiah (Moleong, 2012).

Penelitian ini termasuk dalam kategori penelitian lapangan, yang mana peneliti terjun langsung ke lokasi penelitian untuk mencari data yang valid dan diperlukan untuk keperluan analisis dalam penelitian ini. Data primer yang digunakan adalah wawancara dengan narasumber yang berkaitan langsung dengan inovasi pelayanan "Kumis Mbah Tejo" guna mendapatkan fakta-fakta yang terperinci dan mendalam.

\section{B. LANDASAN TEORI}

Sampai saat sekarang ini masih minim penjelasan secara ilmiah terkait definisi ataupun sesuatu hal yang berkaitan langsung dengan best practice, karena pada dasarnya best practice dianggap hanyalah sebuah predikat yang diberikan terhadap indikator-indikator yang tidak dapat digeneralisasikan ke setiap aspek yang ada. Best practice diartikan sebagai sebuah ide atau cara yang digunakan dan dianggap berhasil dan memiliki tingkat efisiensi dan efektivitas yang tinggi (Pertiwi, 2012). Best practice merupakan praktek terbaik yang dilakukan oleh sebuah otoritas yang biasanya ada didalam Pemerintah atau perusahaan, tergantung kondisinya. Best practice juga menjadi suatu contoh untuk dapat ditiru dan dipraktekkan di tempat yang lain.

Prasojo (2007 : 6) pernah mengutip penilaian UN Habitat tentang best practice dalam konteks lingkungan Perkotaan sebagai inisiatif yang telah menghasilkan kontribusi yang lebih daripada yang lainnya (outstanding contributions) dalam meningkatkan kualitas kehidupan baik di Kota- kota maupun masyarakat umum lainnya. Secara umum UN juga telah menggambarkan melalui beberapa poin utama yang harus dipenuhi, antara lain :

- Memiliki dampak yang dapat ditujukan dan ddiperkenalkan dalam meningkatkan kualitas hidup masyarakat.

- Merupakan hasil dari kerjasama yang efektif antara sektor publik, sektor swasta dan masyarakat pada umumnya.

- Berkelanjutan secara sosial, budaya, ekonomi dan lingkugan.

UN juga telah telah memberikat batasanbatasan yang tertuang dalam kriteria untuk dijadikan alat ukur dalam mengimplementasikan program best practice, kriteriakriteria tersebut antara lain yang telah dtulis oleh Prasojo (2007:7) :

\section{Dampak (impact)}

Sebuat best practice harus menunjukkan sebuah dampak langsung yang positif dan dapat dilihat serta dirasakan untuk meningkatkan kondisi kehidupan masyarakat, terutama masyarakat yang kurang beruntung dalam mendapatkan hak- haknya.

\section{Kemitraan (Partnership)}

Sebuah best practice harus didasarkan pada sebuah kemitraan antara aktor-aktor serta stakeholder yang terlibat didalamnya. Setidaknya ada melibatkan 2 pihak yang saling berintegrasi.

3. Keberlanjutan (Sustainability)

Sebuah best practice harus membawa perubahan dasar dalam wilayah permasalahan Legislasi, kebijakan sosial, kerangka institusional, serta efisiensi, transparan, dan manajemen yang akuntabel.

\section{Kepemimpinan (Leadership)}

Best practice harus digerakkan dengan gaya kepemimpinan yang menginspirasi bagi adanya tindakan dan perubahan, termasuk didalamnya perubahan dalam kebijakan publik yang diambilnya.

\section{Transfer ke daerah lain (Transferbility)}

Setiap daerah yang melakukan inovasi sudah pasti harapanya mendapatkan dampak positif bagi daerahnya. Hal tersebut dapat menjadi lesson- learned atau pembelajaran bagi daerah lainnya sehingga 
penerapannya dapat dicontoh dan dijalankan di daerah tersebut tentunya dengan segala jenis pertimbangan dan penyesuaian dengan konteks lokalnya tersebut.

\section{HASIL DAN PEMBAHASAN}

\section{a. Inovasi Penambahan jam pelayanan \\ "Kumis Mbah Tejo" di Kecamatan \\ Tegalrejo}

Seperti yang sudah dijelaskan sebelumnya bahwa terdapat sebuah inovasi konseptual yang telah dirumuskan oleh pihak Kecamatan Tegalrejo Kota Yogyakarta yaitu penambahan jam pelayanan untuk masyarakat yaitu selama 6 jam setiap minggunya, yang mana setiap kamis dan jumat diberikan tambahan pelayanan 3 jam setiap harinya. Hal tersebut merupakan bukti tanggungjawab Pemerintah Kecamatan tegalrejo dalam meningkatkan kualitas pelayanan dalam meningkatkan kepuasan masyarakat.

Penambahan jam pelayanan ini merupakan ide dari pihak Kecamatan sendiri, dan pertama kali diterapkan pada November 2015. Kenapa bisa muncul Inovasi tambahan jam pelayanan ini karena menjawab dari segala kebutuhan masyarakat yang bekerja di luar kecamatan tegalrejo serta anak sekolah yang baru akan memilki KTP. Inovasi ini muncul tidak begitu saja, ada pembahasan yang mendalam dari pihak Kecamatan Tegalrejo terkait beraninya membuat terobosan dengan menambah jam pelayanan, dengan segala resiko yang ada. Munculnya ide penambahan jam pelayanan berawal dari melihat kondisi masyarakat Tegalrejo yang sebagian besar kerja di luar daerah seperti yang sudah dijelaskan pada BAB I, serta pelajar yang hendak membuat KTP juga berbenturan dengan jadwal sekolah. Maka dari itu pihak demi menjawab kebutuhan masyarakat dengan kondisi seperti itu, maka Kecamatan Tegalrejo memberanikan diri untuk menjalankan inovasi penambahan jam pelayanan.
Penambahan jam pelayanan yang awalnya diberi nama "Jum'at Panjang" yang mana pelayanan di Kecamatan Tegalrejo pada setiap hari Jum'at ada penambahan sebanyak 6 jam dari jam pelayanan normal, yang berarti jam pelayanan sampai jam 20.30 WIB. Jum'at panjang hanya berjalan 1 semester, setelah dievaluasi maka program Jum'at panjang diganti dengan kamis jum'at tambah 3 jam. Untuklebih jelasnya dapat dilihat pada gambar 2 ini :

\section{Gambar 2}

Penambahan Jam Pelayanan di Kecamatan

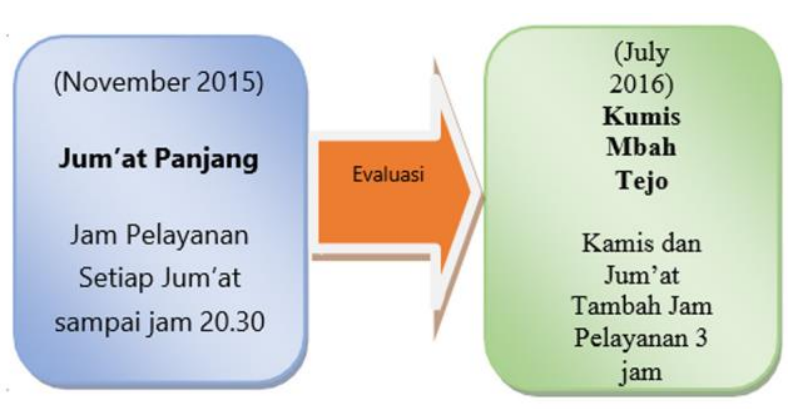

Sebuah Inovasi harus membutuhkan cara untuk memperkenalkan diriya kepada masyarakat, karena sebuah inovasi memerlukan sebuah sarana untuk meyampaikan informasikepada masyarakat terkait inovasi yang ada, penyampaian informasi tentang program tambahan jam pelayanan yang ada di Kantor Kecamatan Tegalrejo dilakukan dengan bantuan keluarahan, diantaranya Kelurahan Tegalrejo, Bener, Kricak, Karangwuri. Setiap Kelurahan yang ada dimanfaatkan untuk membantu dalam mensosialisasikan inovasi penambahan jam pelayanan yang ada di Kecamatan tegalrejo agar lebih efektif. Karena pada dasarnya pihak Kelurahan menjadi instrumen Pemerintah yang paling dekat dengan masyarakat setempat termasuk untuk menyampaikan infomasi apapun yang terkait tentang pelayanan yang ada.

Kordinasi antara Kelurahan sebagai unit pemerintah terkecil dalam melaksanakan pelimpahan wewenang oleh Walikota menjadi 
salah satu kunci keberhasilan penyampaian informasi kepada masyarakat terkait adanya sebuah inovasi pelayanan. Penyampaian informasi tentang penambahan jam pelayanan dilakukan melalui perantara, yang mana perantara yang dimaksud adalah pemerintah Kelurahan demi meningkatkan efisiensi dalam penyampaian informasi. Pihak Kelurahan berkewajiban memberi informasi tersebut kepada masyarakat luas mengenai inovasi pelayanan yang ada di Kecamatana Tegalrejo dengan harapan bisa dimaksimalkan sebaik mungkin.

Selain penyampaian informasi dengan dibantu dengan Pemerintah Kelurahan, Penyebaran informasi juga dilakukan dengan memanfaatkan teknologi yaitu dengan SMS Center. Pemerintah Kecamatan Tegalrejo memiliki SMS Center guna memberi informasi yang efektif dan efisien kepada masyarakat. SMS Center bukan hal yang baru lagi dari Kecamatan Tegalrejo, karena memang pemanfaatan SMS Center ini sudah lama dilakukan dan dampaknya sudah dirasakan oleh masyarakat. Untuk lebih jelasnya dapat dilihat pada gambar 3 dibawah ini :

Gambar 3

\section{Penyampaian informasi Inovasi} "Kumis Mbah Tejo"

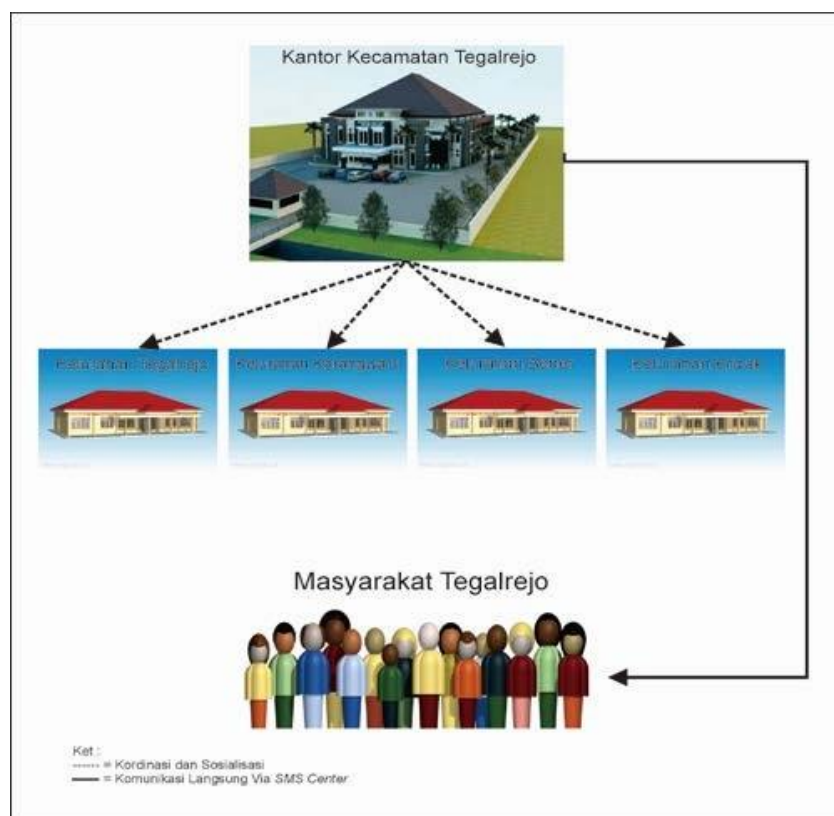

\section{b. Dimensi Impact (Dampak) Inovasi Pelayanan "Kumis Mbah Tejo"}

Indikator yang digunakan dalam dimensi impact ini dalam Inovasi pelayanan "Kumis Mbah Tejo" antara lain dampak langsung yang diterima oleh masyarakat. Pada dasarnya pelaksanaan penambahan jam pelayanan "Kumis Mbah Tejo" ini bertujuan untuk menjawab dari kebutuhan masyarakat dalam memberikan pelayanan yang terbaik. Meskipun demikian pemerintah kecamatan bertanggungjawab penuh dalam pelayanan untuk masyarakat tegalrejo, maka dari itu muncul sebuah inovasi untuk menambahkan jam pelayanan setiap Kamis-Jumat selama 3 jam masing-masing hari. Diharapkan masyarakat mampu memanfaatkan dengan baik inovasi yang dijalankan oleh Pemerintah Kecamatan Tegalrejo.

Tegalrejo merupakan salah satu kecamatan yang berada di wilayah di Kota Yogyakarta. Masyarakat Perkotaan yang memiliki kesibukan dalam kehidupan sehariharinya menjadikan waktu adalah suatu hal yang sangat penting setiap harinya. Upaya terus dilakukan oleh pemerintah Kecamatan Tegalrejo untuk dapat meningkatkan pelayanan yang ada di Kantor Kecamatan. Penambahan jam pelayanan merupakan salah satu upaya untuk dapat menjawab kebutuhan masyarakat Tegalrejo yang sebagian besar masyarakatnya bekerjadi bidang Jasa dan Kantoran.

Masyarakat kota yang berbasis sebagai pekerja kantoran yang berada di luar kecamatan Tegalrejo serta pada bidang jasa, saat ini memiliki kesulitan untuk melakukan urusan administrasi di kecamatan karena berbenturan dengan jam kerja. Pada umumnya masyarakat Tegalrejo bekerja di Magelang, Sleman atau Kulonprogo sekaipun yang mana daerah tersebut berjarak yang cukup jauh dari Kecamatan Tegalrejo dan sangat sulit untuk melakukan pelayanan dengan waktu dan jam kerja normal seperti biasanya. 
Dampak lain yang dirasakan dari Inovasi "Kumis Mbah Tejo" adalah kepada Siswa, yang mana siswa yang sudah cukup umur untuk mendapatkan wajib KTP harus melakukan perekaman data E-KTP. Samasama diketahui bahwa jam sekolah dan jam pelayanan selalu bersamaan, sehingga bagi siswa yang telah wajib KTP mendapatkan kendala ketika hendak melakukan perekaman data. Karena setelah jam sekolah untuk pelayanan di Kantor Kecamatan juga telah tutup sehingga para siswa tidak bisa melakukan merekaman data, yang berdampak saat itu masih minimnya siswa yang wajib KTP namun belum melaukan perekaman data di kantor Kecamatan.

Maka dari hal itu semua inovasi "Kumis Mbah Tejo" memiliki dampak sosial yang langsung dirasakan oleh masyarakat Tegalrejo sendiri, yang mana untuk masyarakat perkotaan yang bekerja di luar daerah Tegalrejo dan sektor jasa serta untuk siswa yang harus melakukan pelayanan secara umum memberi manfaat secara langsung dan nyata untuk menjawab kendala itu semua.

\section{c. Dimensi Partnership (kemitraan) Inovasi Pelayanan "Kumis Mbah Tejo”}

Dimensi partnership akan difokuskan kepada pihak yang terlibat untuk mendukung terlaksanananya dan berjalanya inovasi "Kumis Mbah Tejo" di Kecamatan Tegalrejo. Pada umumnya inovasi yang dilakukan oleh sektor publik atau sektor swasta selalu bekerjasama dengan pihak ketika yang siap membantu segalanya untuk berjalanya suatu inovasi sesuai dengan harapan bersama. Namun dalam kasus "Kumis Mbah Tejo" pemerintah kecamatan tidak bekerjasama dengan pihak ketiga atau pihak swasta, karena ini merupakan inovasi yang terinspirasi dari pemerintah Kecamatan dan cukup hanya bekerjasama dengan pemerintah kelurahan yang berada dibawahnya.

Dalam menjalankan inovasi "Kumis Mbah Tejo" Pemerintah Kecamatan tidak bisa menjalankanya sendiri tanpa bantuan dari pihak manapun, mereka harus bersinergi dengan pemerintah kelurahan agar inovasi tersebut mampu berjalan dengan baik. Karena pada saat pelayanan "Kumis Mbah Tejo" pemerintah kelurahan juga terlibat dan datang untuk melakukan pelayanan di Kantor Kecamatan. Sebab dalam pelayanan "Kumis Mbah Tejo" masyarakat tidak perlu ke kantor kelurahan terlebih dahulu untuk melakukan pelayanan atau sekedar mendapatkan surat pengantar. Hal itu semua karena sudah ada petugas dari kelurahan di Kator Kecamatan saat pelayanan "Kumis Mbah Tejo.

Peran pembagian kerjasama antara pihak Kecamatan dan Kelurahan yang ada yaitu dengan diawali dengan sosialisasi kepada masyarakat yang dilakukan oleh pihak Kelurahan, serta kelurahan uga bertanggungjawab serta terlibat saat jam pelayanan "Kumis Mbah Tejo" dalam bentuk memberikan utusan dari kelurahan untuk berada di kantor Kecamatan saat penambahan jam pelayanan yang ada. Tujuan dari hal itu semua adalah agar masyarakat tidak perlu lagi harus ke kelurahan terlebih dahulu untuk mendapatkan surat pengatar atau lain sebagainya. Sebab, petugas kelurahan juga sudah ada berada di Kecamatan. Hal tersebut selain memudahkan masyarakat, juga dalam bentuk memangkas jarak birokrasi yang ada, jadi masyarakat bisa memanfaatkan penambahan jam pelayanan serta tidak perlu lagi harus ke kantor kelurahan terlebih dahulu.

Pemerintah Kecamatan Tegalrejo dan 4 kelurahan dibawahnya saling bersinergi agar inovasi "Kumis Mbah Tejo" terus berjalan dengan baik, kelurahan yang ada sejak awal sudah bertanggungjawab untuk mensosialisasikan tentang adanya inovasi "Kumis Mbah Tejo” di kantor Kecamatan Tegalrejo kepada masyarakat. Karena peerintah kelurahan dianggap instansi pemerintah yang paling bawah dan sering bertemu langsung dan paling dekat dengan masyarakat. Maka dari itu untuk melakukan sosialisasi inovasi "Kumis Mbah Tejo" selain dengan menggunakan SMS Center seperti yang sudah 
dibahas sebelumnya, Pemerintah Kecamatan juga bekerjasama dengan kelurahan. d. Dimensi Sustainability (keberlanjutan)
Inovasi Pelayanan "Kumis Mbah Tejo"

Pada pembahasan terkait keberlanjutan ini akan terfokus pada beberapa indikator antara legislasi dan dukungan secara berkelanjutan oleh pemerintah diatasnya, yaitu pemerintah Kota Yogyakarta. Meskipun ide dari inovasi pelayanan ini adalah murni dari pemerintah Kecamatan sendiri namun yang namanya Pemerintah sudah pasti harus ada kontrol dan bersinergi dengan pemeritah setingkat diatasnya.

Inovasi “Kumis Mbah Tejo"ini sudah berjalan selama November 2015, yang mana saat itu masih diberi nama Jum'at Panjang oleh Pemerintah Kecamatan yang mana pelayanan dilakukan sampai jam 20.30 pada setiap Jum'at. Namun berjalanya waktu, pada evaluasi di semester I ternyata pemerintah terkendala pada suart pertanggungjawaban (SPJ) yang mana pemerintah Kota Yogyakarta ternyata belum mendukung secara sepenuhnya terhadap model pelayanan yang ada dengan memberikan penambahan jam pelayanan, yang mana itu harus ada pegawai yang harus bekerja diluar dari jam kerja biasanya.

Pemerintah hanya menganggap inovasi "Kumis Mbah Tejo" ini dalam aturan yang ada merupakan hanya sebatas tambahan jam lembur. Padahal dalam konsep yang dilakukan oleh pemerintah kecamatan, harusnya ada penghargaan khusus yang mampu diberikan oleh Pemerintah Kota Yogyakarta untuk insentif khusus kepada pegawai yang mau dan bersedia meluangkan waktunya dalam pelayanan "Kumis Mbah Tejo"demi terwujudnya peningkatan kesejahteraan masyarakat dalam mendapatkan haknya dalam pelayanan.

Sampai saat sekarang ini memang belum ada aturan baik itu dalam bentuk Peraturan Daerah (PERDA) ataupun Peraturan Walikota (PERWALI) Yogyakarta yang mengatur tentang insentif yang diberikan diluar dari jam kerja pada umumnya. Pada aturan sebelumnya dalam hanya membahas tentang adanya uang lembur semata, maka dari itu petugas yang memberi pelayanan pada "Kumis Mbah Tejo" hanya dianggap seperti lembur semata.

Aturan yang berlaku seperti itu yang membuat model pelayanan yang awalnya diberinama Jum'at Panjang dan kemudian diganti dengan pelayanan "Kumis Mbah Tejo" seperti yang masih berjalan sampai saat ini. Sangat disayangkan sekali sebenarnya ketika pemerintah kecamatan sudah mampu memberikan sebuah inovasi yang memberi dampak langsung kepada masyarakat namun pemerintah setingkat diatasnya masih belum mampu membantu dengan aturan ayng ada demi mingkatkan inovasi yang lebih baik lagi.

Pemerintah kecamatan Tegalrejo sudah jelas kedepannya akan lebih baik lagi ada aturan yang mengatur terkait inovasi dan penghargaan yang mampu diberikan kepada setiap instansi yang membuat sebuah inovasi. Karena jika semua itu dilakukan juga akan membuat instansi lain berlomba-lomba dalam memunculkan inovasi di setiap kantor masingmasing. Maka dari itu semua dukungan dari Pemerintah Kota Yogyakarta sangat diharapkan demi keberlanjtan berjalanya inovasi pelayanan "Kumis Mbah Tejo".

\section{e. Dimensi Leadership (kepemimpinan) Inovasi Pelayanan "Kumis Mbah Tejo"}

Analisis terhadap dimensi kepemimpinan termasuk yang cukup berpengaruh karena memang inovasi pelayanan "Kumis Mbah Tejo" merupakan produk inovasi murni yang dikeluarkan oelh Pemerintah Kecamatan sendiri yang dipimpin oleh seorang Ibu Camat yang bernama Sutini.

Ada yang menarik dari munculnya ide penambahan jam pelayanan di Kecamatan Tegalrejo. Kecamatan Tegalrejo dipimpin oleh seorang Ibu Camat yang bernama Sutini, dibawah pimpinan beliau maka penambahan jam pelayanan bisa diterapkan di Kecamatan Tegalrejo. Gaya kepemimpinan sangat 
mempengaruhi dalam suatu kebijakan, jika seorang pemimpin tidak memiliki karakter yang khusus maka sulit untuk menjalankan roda organisasi.

Gaya kepemimpinan situasional yang dimiliki Ibu Camat, yang mana selalu mencoba mengerti dan menyesuaikan dengan kondisi masyarakat sehingga mampu untuk mengambil suatu kebijakan yang mana tujuanya untuk lebih meningkatkan kepuasan masyarakat. Maka dari itu dibalik faktor munculnya ide penambahan jam pelayanan dengan alasan kondisi masyarakat, namun ada hal yang perlu diketahui yaitu gaya kepemimpinan $\mathrm{Bu}$ Camat sebagai pemimpin di Kecamatan Tegalrejo yang mampu mengerti kondisi dan keadaan masyarakat Tegalrejo itu sendiri.

Sudah selama 2 tahun ini pelaksanaan inovasi pelayanan "Kumis Mbah Tejo" dijalankan dibawah kepemimpinan Ibu Camat sendiri, yang mana sudah banyak kendala yang dihadapi agar tetap inovasi ini tetap terus berjalan dengan baik. Terlihat mulai dari perubahan dari model pelayanan Jum'at Panjang saat pertama kali diberlakukan hingga saat ini telah diganti dengan model pelayanan "Kumis Mbah Tejo" meskipun pada kenyataanya masih belum didukung sepenuhnya oleh Pemerintah setingkat diatasnya yaitu Pmerintah Kota Yogyakarta.

Pada kondisi seperti itupun Ibu Camat masih mampu mempertahankan jam pelayanan "Kumis Mbah Tejo" itu sendiri sampai saat sekarang ini, itu semua karena memang inovasi ini masih sangat diperlukan oleh masyarakat Tegalrejo. Ibu Sutini selaku Camatpun mampu memberikan motivasi dan keyakinan kepada pegawai sendiri meskipun untuk menjalankan pelayanan ini butuh pengorbanan yang lebih karena harus bekerja diluar jam kerja biasanya. Meskipun sudah menjalankan inovasi pelayanan ini 2 tahun lamanya, baik pegawai ataupun pemerintah kecamatanpun belum pernah merasakan atau mendapatkan sebuah bentuk penghargaan dari pemerintah setingkat diatasnya, yaitu Pemerintah Kota meskipun Kecamatan
Tegalrejo satu-satunya yang menjalankan inovasi penambahan jam pelayanan seperti ini.

\section{f. Dimensi Transferability \\ (kemungkinan ditiru) Inovasi \\ Pelayanan "Kumis Mbah Tejo"}

Untuk menganalisis Transferability dalam pelaksanaan inovasi penambahan jam pelayanan di Kecamatan Tegalrejo sangat mungkin dan bisa ditiru dan dilakukan di daerah lain. Itu semua karena memang untuk menjalankan atau mengadopsi itu semua tidaklah sulit, sebab tidak perlu mengeluarkan modal yang besar dan mencari pihak ketiga untuk bekerjasama.

Inovasi jam pelayanan "Kumis Mbah Tejo" mampu diimplementasikan karena berdasarkan kebutuhan masyarakat perkotaan yang banyak mampu meluangkan waktunya untuk melakukan pelayanan di Kecamatan Tegalrejo saat sore hari. Hal tersebut karena memang kondisi masyarakat yang bekerja pada umumnya di luar daerah Tegalrejo serta bekerja pada sektor Jasa. Beberapa faktor tersebut memang yang menjadi alasana kenapa Inovasi penambahan jam pelayanan ini bisa muncul dan bertahan sampai saat sekarang ini.

Setiap instansi saat ini memang sedang dituntut oleh pemerintah untuk melakukan sebuah inovasi, yang mana tujuan dari inovasi ini adalah untuk meningkatkan kesejahteraan masyarakat dalam meningkatkan hak-hak masyarakat dalam pelayanan. Namun sebuah inovasi muncul harus mengerti situasi dan kondisi dari kebutuhan masyarakat setempat, karena tujuan dari sebuah inovasi yang paling dasar adalah meningkatkan kualitas pelayanan kepada masyarakat. Jadi tidak bisa begitu saja mengadopsi inovasi yang sudah pernah ada di instansi lain untuk kemudian diterapkan di instansi masing-masing.

Kunci utama dari keberhasilan inovasi pelayanan "Kumis Mbah Tejo" yang ada di Kecamatan Tegalrejo adalah gaya kepemimpinan dari Ibu Camat yang mampu 
menangkap dan mengerti kondisi masyarakat yang dibutuhkan saat ini dalam pelayanan. Pengelolaan manajemen program ini mampu membuat dan menuntut setiap pegawai yang ada untuk mampu memberikan pelayanan yang baik saat jam pelayanan "Kumis Mbah Tejo" meskipun sudah diluar jam kerja pada umumnya.

Maka dari itu pada dasarnya konsep dari inovasi pelayanan "Kumis Mbah Tejo" sangat mungkin diadopsi oleh daerah lain, serta adopsi sistem yang harus menyesuaikan dengan kondisi instansi didaerah masingmasing. Saat ini adopsi sistem sangat mungkin mampu dirubah oleh setiap daerah yang ingin mengadopsi dari inovasi ini, karena memang tujuan dari inovasi ini adalah kepuasan masyarakat. Jadi jika memang kondisi dan keadaan masyarakat yang hampir sama dengan Tegalrejo yang bekerja pada sektor Jasa ataupun bekerja diluar daerah, maka sangat memudahkan sekali untuk diadopsi model penambahan jam pelayanan.

\section{KESIMPULAN}

Inovasi pelayanan "Kumis Mbah Tejo" yang menjadi produk pelayanan unggulan yang ada di Kecamatan tegalrejo Kota Yogyakarta sebagian besar sudah memenuhi indikator pada aspek best practice, dengan mempertimbangkan dimensi- dimensi yang menjadi landasan pada tulisan ini, diantaranya: dimensi dampak, yang mana dampak dari inovasi pelayanan "Kumis Mbah Tejo" ini sangat terasa dan nyata kepada masyarakat, akrena memang masyarakat mampu merasakan dari dampak saat mengimplementasikan inovasi penambahan jam pelayanan ini.

Pada dimensi kemitraan kecamatan Tegalrejo hanya bekerjasama dan bersinergi dengan pemerintah kelurahan yang ada dibawahnya, antara lain Kelurahan Tegalrejo, Kricak, Karangwuru, dan Bener. Untuk keberlanjutan dari Inovasi pelayanan "Kumis Mbah Tejo" ini sudah seharusnya dilanjutkan karena sampai saat sekarang ini masyarakat masih merasa membutuhkan penambahan jam pelayanan ini, namun memang harus perlu adanya dukungan dari Pemerintah Kota Yogyakarta melalui Peraturan serta penghargaan yang harusnya didapatkan oleh setiap instansi yang mampu menjalankan sebuah inovasi yang baik.

Kepemimpinan Ibu Camat juga menjadi kunci kesuksesan pada inovasi jam pelayanan ini, karena beliau mampu mengerti terhadap kondisi masyarakat dan pelayanan seperti apa yang dibutuhkan untuk Tegalrejo sendiri. Pada dimensi terakhir terkait kemungkinan diadopsi oleh daerah lain itu sangat mungkin terjadi karena memang tidak perlu mencari pihak ketiga untuk kerjasama dalam menjalankan inovasi ini dan juga asalakan memiliki karakter masyarakat yang hampir sama kebutuhan model pelayanannya.

\section{DAFTAR PUSTAKA}

Hadjon, P. M., \& dkk. (2011). Hukum Administrasi dan Tindak Pidana Korupsi. Yogyakarta: UGM Press.

Holle, E. S. (2011). Pelayanan Publik Melalui E- Government : Upaya Meminimalisir Praktek Maladministrasi dalam Peningkatan Publik Service. Jurnal Sasi, 21-30.

Juliantara, D. (2005). Peningkatan Kualitas Pemerintah Daerah dalam Pelayanan Publik. Yogyakarta: Pembaruan.

Kasali, R. (2012). Cracking Value. Jakarta: Gramedia Pustaka.

Klitgaard, R. (1998). Membasmi Korupsi. Jakarta: Yayasan Obor Indonesia.

Moleong, L. (2011). Metodelogi Penelitian Kualitatif Edisi Revisi. Bandung: Remaja Rosdakarya. 
Pertiwi, R. (2012). Analisis Best Practice pengelolaan pedagang kaki lima (studi pada relokasi pedagang kaki lima monumen '45 Banjarsari ke Pasar Klitithikan Notoharjo Kota Surakarta). Universitas Indonesia.

Prasojo, Eko, Teguh kurniawan dan Azwar Hasan (2007). Reformasi birokrasi dan inovasi Birokrasi: Studi di Kabupaten Sragen. Jakarta : Yappika. 